\title{
Incidence of Colletotrichum coccodes in Certified Potato Seed Tubers Planted in Washington State
}

\author{
Dennis A. Johnson, Plant Pathologist, Department of Plant Pathology, Washington State University, Pullman, \\ 99164-6430; Randall C. Rowe, Department of Plant Pathology, Ohio State University, Wooster; and Thomas F. \\ Cummings, Department of Plant Pathology, Washington State University
}

\begin{abstract}
Johnson, D. A., Rowe, R. C., and Cummings, T. F. 1997. Incidence of Colletotrichum coccodes in certified potato seed tubers planted in Washington state. Plant Dis. 81:1199-1202.

Incidence of Colletotrichum coccodes in lots of certified seed tubers planted in Washington state, originating from nine western and midwestern states in the United State and two provinces in Canada, ranged from 0 to $90 \%$ in 1994 and 0 to 53\% in 1995. In 1994, significant interactions between state/province and cultivar, and between seed grower and cultivar, were evident. In 1995, incidence of $C$. coccodes in seed lots did not vary significantly among states and cultivars. C. coccodes was not isolated from nuclear seed tubers and incidence of infected tubers was higher with higher seed generations. The fungus was isolated from the tuber periderm and outer medulla tissues and isolation frequency was greater from tuber stem ends than from either bud ends or lateral sections. Significantly greater stem infections developed in plants grown from seed tubers in which $C$. coccodes had been detected than in plants grown from seed tubers from which $C$. coccodes had not been isolated. This study confirms that $C$. coccodes is distributed among potato-production areas within seed tubers, and that seed tuber infection increases the incidence of early-season plant infection.
\end{abstract}

Washington is a major potato-producing state with over 65,900 ha in production in 1996. Seed tubers planted in Washington originate from at least nine western and midwestern states of the United States and two Canadian provinces. Improved understanding of the extent of infestation of seed tubers with various pathogens from different seed-producing areas may help in developing more effective disease management strategies. These strategies could include the planting of seed tubers from areas or farms with relatively low levels of pathogens. Additional strategies might be developed by comparing cultural practices and environmental factors among areas that exhibit different levels of tuber pathogens.

Colletotrichum coccodes (Wallr.) S.J. Hughes, the cause of black dot of potato (Solanum tuberosum L.), is distributed throughout many potato growing regions worldwide $(1,3,7,14,17)$. The soilborne fungus infects all below-ground parts of potato plants and basal stems $(3,13)$, and, in some areas, potato foliage $(6,10)$. It is known to be carried on certified potato seed tubers $(1,8,14,19)$. In Idaho, $C$. coccodes was detected and quantified in $60 \%$ of seed tuber lots. Colonization in tuber

Corresponding author: D. A. Johnson

E-mail: djohnsn@wsu.edu

Accepted for publication 23 July 1997.

Publication no. D-1997-0825-03R

(C) 1997 The American Phytopathological Society stem ends in seed lots ranged from 0 to $10^{3}$ $\mathrm{CFU} / \mathrm{g}$ of tuber tissue, and a high incidence of infected daughter tubers was observed when potatoes were grown in infested soil (1). In Indiana, incidence of $C$. coccodes in certified seed tubers ranged up to nearly $88 \%$ (8). Infected seed tubers can be an important means of introducing the pathogen into new production areas, and may result in early-season plant infection $(1,8)$.

The extent of $C$. coccodes in seed tubers planted in Washington state is not known. Although $C$. coccodes is frequently isolated from the tuber stem end (1), no quantitative data is available on the distribution of the fungus on and within infected seed tubers. The objectives of this work were threefold: (i) determine the incidence of $C$. coccodes in potato seed tubers planted in Washington, (ii) investigate the distribution of $C$. coccodes within tuber tissues, and (iii) confirm the role of seed tuber infection on subsequent infection of potato stems by $C$. coccodes.

\section{MATERIALS AND METHODS}

Certified potato seed tubers that had been produced by commercial seed growers in Idaho, Minnesota, Montana, Nebraska, North Dakota, South Dakota, Oregon, Washington, and Wyoming in the United States, and in Alberta and British Columbia in Canada, were obtained from the potato seed lot performance trials conducted at the Washington State University Agricultural Research Station near Othello, Washington. In 1994, 20 to 30 tubers were selected at random from each of 284 seed lots; in 1995, 20 tubers from each of 103 seed lots were selected. Tubers were washed in running tap water to remove soil, surface disinfested for $3 \mathrm{~min}$ in $1 \%$ $\mathrm{NaOCl}$, and then air dried. In 1994, a slice of periderm and medulla tissue about $1 \mathrm{~cm}$ in diameter and $3 \mathrm{~mm}$ thick was cut from the stem end of each tuber and placed on potato extract media (7) in petri dishes. In 1995, a slice about $6 \mathrm{~mm}$ deep was removed from the stem end of each tuber and discarded. Then four 3- to 5-mm-diameter pieces of the exposed vascular tissues were excised from each tuber slice with a sterile scalpel and placed on NPX agar medium (2). After plating, all petri dishes were incubated at 21 to $23^{\circ} \mathrm{C}$ on a laboratory bench for 10 to 14 days, at which time tissue pieces and agar media were observed for growth of $C$. coccodes using a stereo dissecting scope.

Certified seed tubers of the cultivar Russet Burbank produced in Montana and Washington were used in the following experiments, unless otherwise specified. To determine the level of $C$. coccodes in different generations of potato seed tubers, nuclear through generation-3 seed tubers were obtained from one Montana seed grower in 1995 and two Montana seed growers in 1996. Additionally, seed tubers of generation 2 and generation 3 were obtained from four and nine different Montana seed growers, respectively, in 1995. Nuclear seed tubers were produced in greenhouses from tissue cultured plantlets; generation 1 seed tubers were grown in fields on which potatoes had not previously been grown or had not been grown for at least 10 years; and generations 2 and 3 seed tubers were grown in fields in which potatoes had not been grown for 4 to 5 years. The stem ends of 50 tubers per generation in 1995, and 30 to 60 tubers per generation in 1996, were excised and plated on NPX medium and incubated as above. Colonies of $C$. coccodes were identified and incidence of infected tubers per generation determined.

To determine the occurrence of $C$. coccodes within different seed tuber tissues, the periderm and medulla tissues from tuber stem ends, lateral surface mid-sections, and bud end tissues from 460 tubers representing 13 certified seed lots were assayed for $C$. coccodes.

To determine if $C$. coccodes colonized the outer medulla tuber tissue, 84 tubers 
commercially grown near Othello, Washington were washed and treated with $\mathrm{NaOCl}$ as previously described. The stem end of each tuber was dipped in $95 \%$ ethyl alcohol for $10 \mathrm{sec}$ and then flamed for 10 to $12 \mathrm{sec}$. A slice of the medulla was then removed, plated, and incubated as previously described. In another experiment, 66 seed tubers were washed and treated with $\mathrm{NaOCl}$ as before, and the stem ends of 48 seed tubers were thinly peeled. Half of the peeled stem ends were dipped in $95 \%$ ethyl alcohol for $10 \mathrm{~min}$ and flamed off as above, while the others were not alcoholtreated. The stem ends of the remaining 18 seed tubers were left non-peeled and nonflamed. A slice of the stem end of each tuber was plated and incubated as previ-

To determine the extent of stem infection in plants grown from infected seed pieces, plants from seed pieces cut from tubers either naturally infected or inoculated with $C$. coccodes, and tubers in which $C$. coccodes was not detected prior to cutting, were grown in a potting mix (3:1:1 mixture of peat moss, pumice, and sand) in four experiments. Naturally infected seed inoculated seed pieces in a fourth. In each experiment, stem ends of certified seed tubers were assayed for $C$. coccodes by excising and plating on NPX using previously described procedures. Seed tubers in which $C$. coccodes was detected or not detected were identified. Plants were grown from buds cut from these tubers with a disk-shaped cutter that produced a ously described. tubers were used in three experiments and

sphere of tuber tissue about $13 \mathrm{~g}$ in weight in the first and fourth experiments, and from an approximately 42-g seed piece cut from tuber stem ends in the second and third experiments. The number of plants from seed tubers infected with $C$. coccodes and from those in which the pathogen was not detected, respectively, was 10 and 27 in the first, 20 and 12 in the second, and 23 and 26 in the third experiment. The number of inoculated and non-inoculated seed pieces used in the fourth experiment was 27 and 33, respectively.

Seed tubers in which $C$. coccodes was not detected were used in the fourth experiment. Some tuber sphere pieces were inoculated by placing them into a $1,000-\mathrm{ml}$ beaker with a suspension of $1.9 \times 10^{6} C$. coccodes conidia/ml. Control tuber spheres were immersed in distilled water. In both cases, beakers containing treated spheres were placed in a vacuum desiccator jar and subjected to a partial vacuum of about 450 $\mathrm{mm}$ of mercury for $2 \mathrm{~min}$. Inoculated and non-inoculated seed pieces were placed on paper towels and allowed to dry at $21^{\circ} \mathrm{C}$ for $24 \mathrm{~h}$ before planting.

Plants were grown in a greenhouse for $33,42,56$, and 37 days, respectively, in the four experiments at temperatures of 21 to $26^{\circ} \mathrm{C}$ during the day and 17 to $20^{\circ} \mathrm{C}$ at night. Supplemental lights were not used, as all experiments were done in the spring when photoperiods exceeded $13 \mathrm{~h}$. After growth, plants were uprooted and stem sections were collected from each plant. Stem sections were cut with a flamed scalpel, washed in running water, and surface

Table 1. Detection of Colletotrichum coccodes in seed tubers in 1994 and 1995

\begin{tabular}{|c|c|c|c|c|}
\hline \multirow[b]{2}{*}{$\begin{array}{l}\text { Percentage of tubers in which } \\
\text { C. coccodes was detected }\end{array}$} & \multicolumn{2}{|c|}{$1994^{y}$} & \multicolumn{2}{|c|}{$1995^{z}$} \\
\hline & $\begin{array}{l}\text { Number of } \\
\text { seed lots }\end{array}$ & $\begin{array}{l}\text { Percentage of } \\
\text { total tested }\end{array}$ & $\begin{array}{l}\text { Number of } \\
\text { seed lots }\end{array}$ & $\begin{array}{l}\text { Percentage of } \\
\text { total tested }\end{array}$ \\
\hline 0 & 56 & 20 & 55 & 53 \\
\hline $1-5$ & 20 & 7 & 21 & 20 \\
\hline $6-10$ & 19 & 7 & 10 & 10 \\
\hline $11-20$ & 34 & 12 & 11 & 11 \\
\hline $21-30$ & 46 & 16 & 3 & 3 \\
\hline $31-40$ & 41 & 14 & 1 & 1 \\
\hline $41-50$ & 27 & 10 & 1 & 1 \\
\hline $51-60$ & 18 & 6 & 1 & 1 \\
\hline $61-70$ & 12 & 4 & 0 & 0 \\
\hline $71-80$ & 6 & 2 & 0 & 0 \\
\hline $81--90$ & 5 & 2 & 0 & 0 \\
\hline
\end{tabular}

y Twenty to 30 tubers tested in each of 284 seed lots.

${ }^{\mathrm{z}}$ Twenty tubers tested in each of 103 seed lots.

Table 2. Mean percentage of seed tubers from various seed lots of four potato cultivars from one Canadian province and five U.S. states in which Colletotrichum coccodes was detected ${ }^{\mathrm{z}}$ in 1994

\begin{tabular}{lcccc}
\hline & Russet Burbank & Ranger Russet & Russet Norkota & Shepody \\
\hline Alberta & $11(20) \mathrm{a}$ & $23(4) \mathrm{a}$ & $26(6) \mathrm{a}$ & $18(5) \mathrm{a}$ \\
Idaho & $47(6) \mathrm{b}$ & $18(3) \mathrm{ab}$ & $0(1) \mathrm{a}$ & $\ldots$ \\
Montana & $31(92) \mathrm{ab}$ & $30(2) \mathrm{ab}$ & $22(16) \mathrm{a}$ & $49(4) \mathrm{b}$ \\
Nebraska & $\ldots$ & $18(10) \mathrm{a}$ & $12(6) \mathrm{a}$ & $20(3) \mathrm{a}$ \\
North Dakota & $85(1) \mathrm{c}$ & $13(3) \mathrm{ac}$ & $45(15) \mathrm{bd}$ & $36(7) \mathrm{ab}$ \\
Washington & $30(12) \mathrm{b}$ & $9(4) \mathrm{ab}$ & $10(8) \mathrm{a}$ & $4(2) \mathrm{ab}$ \\
\hline
\end{tabular}

${ }^{\mathrm{z}}$ Numbers in parenthesis are number of seed lots tested. Values within columns followed by same letter are not significantly different $(P>0.05)$ using least significant difference test. disinfested in $0.5 \% \mathrm{NaOCl}$ for $3 \mathrm{~min}$. Four 3 -cm stem sections located 2, 7, 12, and 17 $\mathrm{cm}$ above the seed piece of each stem were removed in experiments 1 and 2 . In experiments 3 and 4 , two 3 -cm stem sections were removed 2 and $7 \mathrm{~cm}$ above each seed piece. Stem sections were then placed on moist filter paper in a petri dish. Approximately $0.25 \mathrm{ml}$ of a $0.015 \%$ solution of Gramoxone (20.4\% paraquat), a desiccant herbicide, was then applied to each stem section to promote fungal sporulation (16). Stem sections were incubated at 21 to $23^{\circ} \mathrm{C}$ on a laboratory bench and then observed for $C$. coccodes growth with a stereo dissecting scope.

Disease incidence data for tubers infected with $C$. coccodes from the various seed lots were analyzed using two-way analysis of variance for a completely randomized, unbalanced design (SAS, general linear models procedure, SAS Institute, Cary, NC). In 1994, 2 to 10 seed lots each from 43 seed growers in Idaho, Alberta, Washington, and Montana were included in these studies. Disease incidence data from these lots were analyzed using a two-way analysis of variance to test for differences among individual seed growers. Linear regression was used to test for an increase in the incidence of infected seed with higher seed generation. The probability of detecting $C$. coccodes in seed tubers, assuming that the fungus (if present) would be detected if isolations were made from the stem end, a lateral section, and the bud end, was made by comparing the number of successful isolations at a specific tuber location to the total number of tubers. Student's $t$ test was used to test for significant differences between infected plants that developed from seed pieces from which $C$. coccodes had or had not been isolated.

\section{RESULTS}

Incidence of $C$. coccodes in seed lots ranged from 0 to $90 \%$ in 1994 and from 0 to $53 \%$ in 1995 (Table 1). C. coccodes was isolated from seed lots from every seedproducing state or province tested, and from seed lots of most cultivars from each of the seed-producing states or provinces.

In 1994, incidence of $C$. coccodes in seed lots varied significantly $(P=0.0006)$ among states, but not cultivars $(P=0.068$; Table 2). A significant interaction $(P=$ $0.0029)$ between states or provinces and cultivar was evident in 1994. There was a significant difference in incidence of $C$. coccodes in seed among the 43 seed growers $(P=0.0001)$, but not among cultivars $(P=0.45)$. A significant interaction was evident between grower and cultivar $(P=$ 0.049). In 1995, incidence of $C$. coccodes in seed lots did not vary significantly among states $(P=0.17)$ or cultivars $(P=$ $0.20)$.

C. coccodes was not isolated from nuclear seed, and was isolated from only one 
of three lots of generation 1 seed (Table 3 ). Incidence of infected tubers increased with higher seed generation from the same source $(P<0.01)$. In samples of generation 2 and 3 seed lots from different grower sources, mean incidence of tubers with $C$. coccodes in four seed lots of generation 2 seed and nine seed lots of generation 3 seed was 33 and $50 \%$, respectively. The difference was not significant when tested with student's $t$ test $(P=0.05)$.

$C$. coccodes was isolated more frequently from the stem end than from either the bud end or lateral section of tubers (Table 4). The probability of isolating $C$. coccodes from infected tubers was 80,33 , and $19 \%$, if isolations were made only from the stem end, lateral section, or bud end, respectively. The probability of detecting C. coccodes was $94 \%$ if isolations were made from the stem end and a lateral section, and $87 \%$ if isolations were made from the stem and bud ends.

C. coccodes was isolated from the stem end of 15 of 84 tubers that were dipped in alcohol and then flamed for 10 to $12 \mathrm{sec}$. The fungus was isolated from 12 of 18 tubers, 6 of 24, and 2 of 24 tubers that were left unpeeled; peeled; or peeled, dipped in alcohol and flamed; respectively.

In three studies, significantly $(P=0.01)$ more stems were infected with $C$. coccodes that originated from seed tubers naturally infected with the fungus than from tubers from which the fungus was not detected (Table 5). C. coccodes was detected in stem sections farther from the seed piece of stems that originated from infected seed pieces than in stems from tubers in which the fungus was not detected. In the first experiment, when stems originated from infected seed, incidence of $C$. coccodes in the first, second, third, and fourth stem section above the seed piece was 50, 30, 30 , and $20 \%$, respectively. The fungus was only detected in the first stem section from seed in which the fungus was not detected. In the second experiment, $C$. coccodes was only detected in the stem section closest to the seed piece. In the third experiment, $C$. coccodes was detected in $48 \%$ of the first stem sections and $43 \%$ of the second stem section when stems originated from infected seed. The fungus was detected in 4 and $11.5 \%$, respectively, of the first and second stem sections when stems originated from seed in which the fungus was not detected.

The incidence of infected stems arising from seed pieces inoculated with $C$. coccodes was $74 \%$, whereas it was only $6 \%$ in stems from noninoculated seed pieces. The difference was significant $(P=0.01)$. The fungus was detected in 70 and $37 \%$, respectively, of the first and second stem sections when tubers were inoculated, and 3 and $6 \%$, respectively, of the first and second stem sections when tubers were not inoculated.

\section{DISCUSSION}

A high incidence of $C$. coccodes was found in certified potato seed tubers originating from various sources and geographic areas in western North America. $C$. coccodes has been reported from potato seed tubers previously, but its incidence within seed lots from such a wide area has not been quantified. C. coccodes was not detected in several seed lots from some states and provinces, indicating some seed sources can be relatively free of the pathogen. Barkdoll and Davis (1) also found some seed sources in southern Idaho with little or no C. coccodes, and they could not detect the fungus in soils from native vegetation sites. The incidence of infected seed tubers in this study increased with higher seed tuber generations when seed potatoes were grown in fields previously or more recently cropped to potato, and thus most likely infested with $C$. coccodes. This indicates that infested soil in seed tuber production areas is a likely source of the pathogen.

Infected seed is a known means of disseminating this pathogen $(1,8)$ which leads to early-season plant infection (8). Planting heavily infected seed tubers might negate the effects of pre-plant soil treatments and long rotations between potato crops. This study confirms the potential for relatively high amounts of plant infection to arise from infected tubers, as reported by Komm and Stevenson (8). Infected stems in control plants probably arose from infected seed tubers in which the pathogen had gone undetected. Infected seed may explain the detection of $C$. coccodes in Russet Burbank potato plants early in the production season in Washington (7).

C. coccodes was detected less frequently in 1995 than in 1994 because in 1995 isolations were made only from vascular tissues further from the periderm. In this study, C. coccodes was found over the entire surface of tubers and relatively deep in the medulla. However, C. coccodes was located mostly in the peel material (periderm). In a previous study, C. coccodes was also isolated from superficial spots and blotches on the tuber periderm and from deeper tissues within tubers (11). C. coccodes was detected more frequently from the stem end than from other areas of tubers, possibly indicating infections asso-

Table 3. Percentage of tubers with Colletotrichum coccodes in four seed tuber generations from three sources

\begin{tabular}{lcccc}
\hline & $\mathbf{1 9 9 5}$ & & $\mathbf{1 9 9 6}$ \\
\cline { 2 - 5 } \cline { 5 - 5 } Generation & Source 1 $^{\mathbf{x}}$ & & Source 2 $^{\mathbf{y}}$ & Source 3 $^{\mathbf{z}}$ \\
\hline Nuclear & 0 & 0 & 0 \\
Generation 1 & 0 & 3 & 0 \\
Generation 2 & 2 & 7 & 40 \\
Generation 3 & 14 & 25 & 43 \\
\hline
\end{tabular}

${ }^{x}$ Sample size was 50 tubers/generation.

y Sample size was 60 tubers/generation for G1 to G3 and 30 tubers for nuclear.

${ }^{\mathrm{z}}$ Sample size was 30 tubers/generation.

Table 4. Detection of Colletotrichum coccodes in stem end, lateral section, and bud end tissues of infected tubers from 13 seed lots

\begin{tabular}{lccc}
\hline & \multicolumn{2}{c}{ Tuber section $^{\mathbf{z}}$} & \\
\cline { 2 - 3 } Stem & Lateral & Bud & Percentage of detection \\
\hline+ & - & - & 55.8 \\
- & + & - & 12.5 \\
- & - & + & 5.3 \\
+ & + & - & 12.0 \\
+ & - & + & 5.6 \\
- & + & + & 2.3 \\
+ & + & + & 6.5 \\
\hline
\end{tabular}

$\bar{z}+$ and - indicate that $C$. coccodes was and was not isolated, respectively. Sample size was 16 tubers in one lot, 24 in six lots, and 50 in six lots.

Table 5. Percentage of potato stems from which Colletotrichum coccodes was isolated in three experiments, in which stems originated either from infected seed tuber pieces or seed tuber pieces from which C. coccodes had not been detected

\begin{tabular}{lcc}
\hline & \multicolumn{2}{c}{ Incidence of infected stems } \\
\cline { 2 - 3 } Experiment & C. coccodes detected in seed tubers & C. coccodes $\begin{array}{c}\text { not detected in seed } \\
\text { tubers }\end{array}$ \\
\hline I & $50^{\mathrm{z}}$ & 11 \\
II & $70^{\mathrm{z}}$ & 0 \\
III & $52^{\mathrm{z}}$ & 12 \\
\hline
\end{tabular}

${ }^{\mathrm{z}}$ Significantly different from those originating from tubers with no $C$. coccodes detected, $P=0.01$. 
ciated with the stolon. Probabilities of detecting $C$. coccodes from tubers were based on tubers from which the fungus was isolated and there probably were infected tubers from which $C$. coccodes was not detected. This would lower actual probabilities.

The direct effects of $C$. coccodes infection on potato yield are not well understood. The fungus has been shown to cause severe disease symptoms $(1,4,18)$ and latent infections $(1,5,7)$ in potato, and to reduce potato yields in controlled, replicated, inoculation experiments $(1,5,10,17)$. However, some investigators do not consider $C$. coccodes capable of detrimentally affecting yields, or believe it can do so only when interacting with other pathogens or abiotic factors $(3,9,12,15)$. Results of this study have demonstrated that any portion of the tuber surface may be infected with $C$. coccodes and that subsequent stem infection may result. Detecting all infected seed in a seed lot is not possible because the fungus can occupy any surface area or be located in the outer medulla tissue. Experiments designed to determine the effect of $C$. coccodes on potato yield may be compromised if either undetected, infected potato seed tubers that give rise to infected plants are used in the "non-infected controls," or if latent infections which occur in potato $(5,7)$ are not detected. Both of these factors need to be considered in further studies designed to determine the effects of C. coccodes on potato yield.

\section{ACKNOWLEDGMENTS}

Plant Pathology New Series No. 0248, Project No. 0678, College of Agriculture and Home Economics Research Center, Washington State University, Pullman 99164.

\section{LITERATURE CITED}

1. Barkdoll, A. W., and Davis, J. R. 1992. Distribution of Colletotrichum coccodes in Idaho and variation in pathogenicity on potato. Plant Dis. 76:131-135.

2. Butterfield, E. J., and DeVay, J. E. 1977. Reassessment of soil assays for Verticillium dahliae. Phytopathology 67:1073-1078.

3. Dickson, B. T. 1926. The "black dot" disease of potato. Phytopathology 16:23-40.

4. Forlot, P. 1967. Recherches sur les interactions de Colletotrichum coccodes (Wallr.) Hughes et de ses hotes principaux: Solanum tuberosum L. et Lycopersicum esculentum L. Phytopathol. Z. 59:247-266.

5. Johnson, D. A. 1994. Effect of foliar infection caused by Colletotrichum coccodes on yield of Russet Burbank potato. Plant Dis. 78:10751078.

6. Johnson, D. A., and Miliczky, E. R. 1993. Effects of wounding and wetting duration on infection of potato foliage by Colletotrichum coccodes. Plant Dis. 77:13-17.

7. Johnson, D. A., and Miliczky, E. R. 1993. Distribution and development of black dot, Verticillium wilt, and powdery scab on Russet Burbank potatoes in Washington State. Plant Dis. 77:74-79.

8. Komm, D. A., and Stevenson, W. R. 1978. Tuber-borne infection of Solanum tuberosum 'Superior' by Colletotrichum coccodes. Plant Dis. Rep. 62:682-687.

9. Kotcon, J. B., Rouse, D. I., and Mitchell, J. E. 1985. Interactions of Verticillium dahliae, Colletotrichum coccodes, Rhizoctonia solani, and Pratylenchus penetrans in the early dying syndrome of Russet Burbank potatoes. Phyto- pathology 75:68-74.

10. Mohan, S. K., Davis, J. R., Sorensen, L. H., and Schneider, A. T. 1992. Infection of aerial parts of potato plants by Colletotrichum $\mathrm{coc}$ codes and its effects on premature vine death and yield. Am. Potato J. 69:547-559.

11. Mooi, J. C. 1959. A skin necrosis occurring on potato tubers affected by black dot (Colletotrichum atramentarium) after exposure to low temperatures. Eur. Potato J. 2:5868.

12. Otazu, V., Gudmestad, N. C., and Zink, R. T. 1978. The role of Colletotrichum atramentarium in the potato wilt complex in North Dakota. Plant Dis. Rep. 62:847-851.

13. Pavlista, A., and Kerr, E. D. 1992. Black dot of potato caused by Colletotrichum coccodes in Nebraska. Plant Dis. 76:1077.

14. Read, P. J., and Hide, G. A. 1988. Effects of inoculum source and irrigation on black dot disease of potatoes (Colletotrichum coccodes (Wallr.) Hughes) and its development during storage. Potato Res. 31:493-500.

15. Scholte, K., Veenbaas-Rijks, J. W., and Labruyere, R. E. 1985. Potato growing in short rotations and the effect of Streptomyces spp., Colletotrichum coccodes, Fusarium sambucinum, and Verticillium dahliae on plant growth and tuber yield. Potato Research 28:331-348.

16. Sinclair, J. B. 1991. Latent infection of soybean plants and seeds by fungi. Plant Dis. 75:220-224.

17. Stevenson, W. R., Green, R. J., and Bergeson, G. B. 1976. Occurrence and control of potato black dot root rot in Indiana. Plant Dis. Rep. 60:248-251.

18. Thirumalachar, M. J. 1967. Pathogenicity of Colletotrichum atramentarium on some potato varieties. Am. Potato J. 44:241-244.

19. Uribe, E., and Loria, R. 1994. Response of Colletotrichum coccodes to fungicides in vitro. Am. Potato J. 71:455-465. 